\title{
Heavy Metals in the Bottom Sediments of the Black Sea Northwestern Shelf in Recent Years
}

\author{
I. V. Korablina ${ }^{凶}$, T. O. Barabashin, N. I. Katalevsky \\ Russian Federal Research Institute of Fisheries and Oceanography "VNIRO” \\ Azov-Black Sea Branch of VNIRO (“Azniirkh”), \\ Rostov-on-Don, Russian Federation \\ 凶korablina_i_v@azniirkh.ru
}

\begin{abstract}
Purpose. The study is aimed at investigating metal accumulation in the $0-2 \mathrm{~cm}$ layer of the bottom sediments of the Black Sea northwestern shelf over 2000-2020, and at identifying the sea bottom areas subjected to the increased anthropogenic load through comprehensive assessment of the degree of their pollution taking into account their granulometric composition.

Methods and Results. The bottom sediments were sampled annually from the $0-2 \mathrm{~cm}$ depth at the same stations. The detected metal concentrations were compared with their content in the Earth crust and the background values. The dynamics and trends of the individual metals' content in the shelf bottom sediments were assessed for the whole period of observations. The notion of the average characteristic concentration of an element is introduced; the procedure for its calculation is represented. The pollution of bottom sediments was analyzed with the regard for the element average characteristic concentration in the bottom sediments of various granulometric types. Increase in the average content of lead, zinc and chromium was revealed from the beginning of the observation period to 2020. The seasonal dynamics of these elements was found in the whole water area under study (as well as the iron content at some areas).

Conclusions. Multiple cases of the lead, manganese and chrome concentrations exceeding their content in the Earth crust were recorded; as for zinc and copper, such cases were few and sporadic. The tendencies in variation of the bottom sediments content were determined: the average long-term values of the lead concentration increased by 1.2 times, those of zinc - by 1.6 times, and those of chrome - by 2 times; the concentrations of iron, manganese and copper remained essentially the same. Seasonal dynamics of the zinc, chromium, lead and iron content was shown. For a number of metals, the cases when their absolute content exceeded their average characteristic concentration in the corresponding type of the bottom sediments had been found. The regions subjected to a multifaceted anthropogenic load were identified; the areas of possible local inflow of the monitored elements were revealed. The bottom sediments sampled in 2019 were the most polluted.
\end{abstract}

Keywords: Black Sea, bottom sediments, shelf, pollution, heavy metals, average characteristic concentration

Acknowledgments: the work was carried out within the framework of the state task "Implementation of state monitoring of aquatic biological resources in internal waters, in the territorial sea of the Russian Federation, on the continental shelf of the Russian Federation and in the exclusive economic zone of the Russian Federation, in the Azov and Caspian seas" (section 5 of the state task of the Russian Federal Research Institute of Fisheries and Oceanography “VNIRO” No. 076-00005-20-02).

For citation: Korablina, I.V., Barabashin, T.O. and Katalevsky, N.I., 2021. Heavy Metals in the Bottom Sediments of the Black Sea Northwestern Shelf in Recent Years. Physical Oceanography, [e-journal] 28(5), pp. 549-566. doi:10.22449/1573-160X-2021-5-549-566

DOI: 10.22449/1573-160X-2021-5-549-566

(C) I. V. Korablina, T. O. Barabashin, N. I. Katalevsky, 2021

(C) Physical Oceanography, 2021

\section{Introduction}

In environmental monitoring of water bodies, in a number of cases, bottom sediments are the most informative research object [1]. An important pollution indicator of any water area is the content of metals in bottom sediments. This is due ISSN 1573-160X PHYSICAL OCEANOGRAPHY VOL. 28 ISS. 5 (2021) 
to the fact that the chemical composition of bottom sediments, in contrast to the aquatic environment, carries information about the general state of the ecosystem, as well as about both the natural and anthropogenic components of pollution over a long period of time. At the same time, in the presence of a sufficiently large amount of data this provides tracking of more subtle patterns of the ecosystem pollution dynamics [2]. This parameter is required to characterize the level of the load on the water body [3].

Bottom sediments are a complex physicochemical system. The solid phase is represented by mineral matter and organic residues, the liquid phase - by pore water captured by the sediment during its formation from the bottom water and subject to transformation during the diagenesis of bottom sediments [4]. Having got into the surface layers of water, heavy metals pass in the process of transfer and transformation to the final point of the chain - bottom sediments. As a result of accumulation, their content in the bottom sediments can be much higher than their concentration in the water column. At the same time, burial in the sediment layer is not always the final link. Due to the activity of microflora, heavy metals, converted into intermediate products, can return to the marine environment. In coastal and shallow water zones, under effect of wave and wind activity, as well as biological roiling by mollusks, bottom sediments become a source of secondary water pollution [5].

In Russia, the interpretation of the results of bottom sediments analysis is difficult due to the lack of approved standards for the content of controlled substances (similar to the MPC for the water). Therefore, the concentration of these substances, obtained as a result of research, is usually compared with their average content in the Earth's crust or with background indicators.

The problem of this research included a generalized assessment of the heavy metals content in bottom sediments of the Black Sea northeastern part after 2000 and identifying trends in the spatial distribution of heavy metals, taking into account the concentrations characteristic of various granulometric types of bottom sediments.

\section{Materials and methods}

The work is based on the generalization of materials collected during expeditionary observations of the Azov-Black Sea branch of FSBSI "VNIRO" ("AzNIIRKH") on the shelf of the Black Sea northeastern part in 2000-2020. Bottom sediment samples were taken twice a year (in May - June and in August September) at 22 standard stations from 20-70 m depths from the Kerch pre-strait to the mouth of the Mzymta River (Fig. 1).

Upon delivery to the laboratory, each sample was thoroughly mixed with a porcelain spoon, foreign inclusions (stones, algae, etc.) were removed. Preliminary preparation included drying to constant weight, sieving through a nylon sieve, grinding, and tableting. The content of iron, manganese, zinc, chromium, lead and copper was determined by X-ray fluorescence analysis method according to the methodology developed in the Azov-Black Sea branch of FSBSI "VNIRO" (“AzNIIRKH”) and approved for monitoring environmental studies at the federal level [6, 7], using a Rigaku X-ray spectrometer (Japan) and an X-ray apparatus for spectral analysis "SPECTROSCAN MAKS-GVM" (Russia). In total, more than 800 samples of bottom sediments were taken and processed.

PHYSICAL OCEANOGRAPHY VOL. 28 ISS. 5 (2021) 


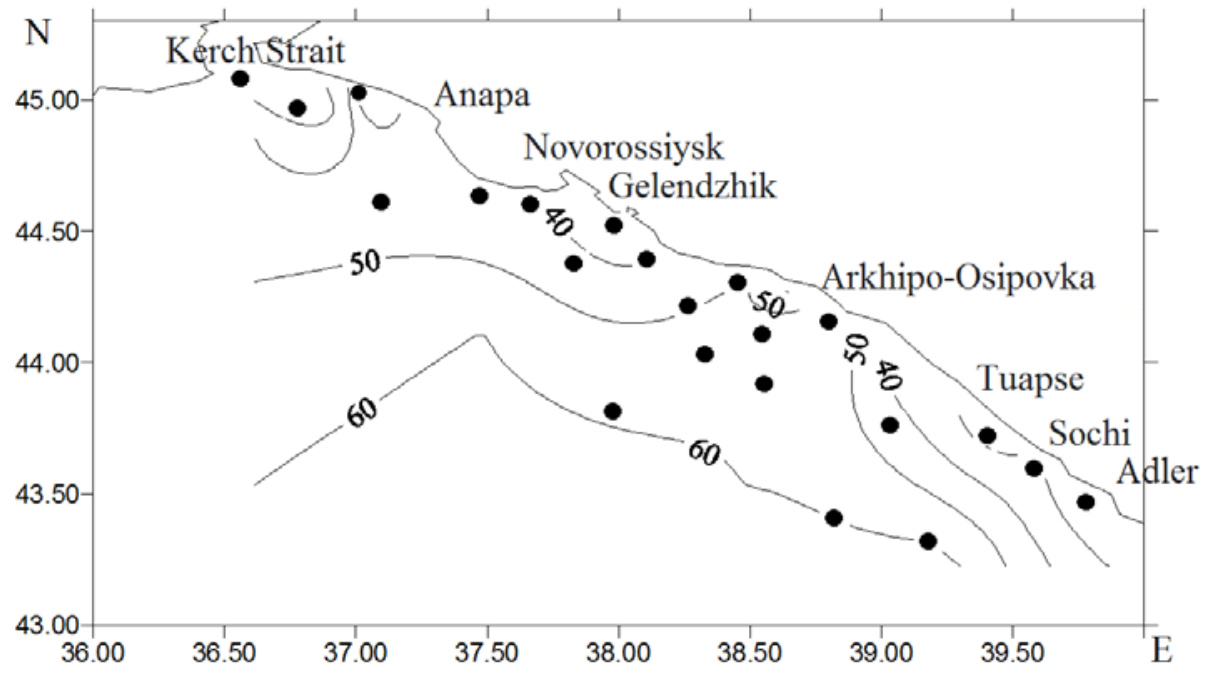

F i g. 1. Schematic map of bottom sediment sampling stations on the Black Sea shelf (with isobaths), 2000-2020

The construction of the calibration characteristics was carried out using certified standardized samples of domestic production: typical black soil composition (TCC set) GSO 2507-83-2509-83; the soddy-podzolic sandy loam soil composition (SPSLSC set) state standard sample of a substance or material, the composition of which is established as a result of tests (GSO) 2498-83-2500-83; the red soil composition (RSC set) GSO 250183-2503-83); the calcareous sierozem soil (CSS set) GSO 2504-83-2506-83; bottom sediment "terrigenous clay" (SDO-1) GSO 1757-80; bottom sediment “volcano-terrigenous silt” (SDO-2) GSO 1756-80; bottom sediment "lime-silt" (SDO-3) GSO 1758-80; bottom sediment "carbonate background silt” (SGH-1) GSO 3131-85; bottom sediment “anomalous silt” (SGH-5) GSO 3133-85.

\section{Results and discussion}

During the observation period (2000-2020) in the bottom sediments of the shelf of the Black Sea northeastern part, the cases of excess of the manganese detected concentrations over the average content in the Earth's crust were noted in 2004-2005, 2007-2009 and 2011-2019 with a maximum multiplicity that did not exceed 1.3; chrome - in 2005, 2009, 2012, 2014-2020 with a multiplicity greater than 2. From the list of monitored metals for 20 years of observations, only the iron content did not significantly exceed its content in the Earth's crust (Table 1). Such a non-uniform dynamics of the metal content was determined by the local sources of their input. The zoning of the surveyed water area with reference to possible sources of anthropogenic influx of metals into the sea showed that during the observation period the maximum lead concentrations in the bottom sediments were recorded in 2004 at the exit from the Tsemess Bay, copper in 2011, iron in 2014 and manganese in 2020 in the Kerch pre-strait, zinc and chromium in 2018 abeam the mouth of the Mzymta River. 
Ranges of heavy metals content, $\mathrm{mg} / \mathrm{kg}$ dry weight, in the bottom sediments of the Black Sea northeastern shelf in 2000-2020

\begin{tabular}{|c|c|c|c|c|c|c|c|c|c|c|c|}
\hline \multirow{2}{*}{ Metal } & \multicolumn{11}{|c|}{ Content in bottom sediments } \\
\hline & 2000 & 2001 & 2002 & 2003 & 2004 & 2005 & 2006 & 2007 & 2008 & 2009 & 2010 \\
\hline Iron & $\begin{array}{l}4320- \\
22500\end{array}$ & $\begin{array}{c}8560- \\
22100\end{array}$ & $\begin{array}{l}9670- \\
39230\end{array}$ & $\begin{array}{l}1479- \\
37140\end{array}$ & $\begin{array}{l}1860- \\
39480\end{array}$ & $\begin{array}{l}6030- \\
38580\end{array}$ & $\begin{array}{l}4420- \\
39190\end{array}$ & $\begin{array}{l}4330- \\
37550\end{array}$ & \begin{tabular}{|l}
$2654-$ \\
37210
\end{tabular} & \begin{tabular}{|l}
$3728-$ \\
39242
\end{tabular} & $\begin{array}{l}3840- \\
37745\end{array}$ \\
\hline Manganese & $\begin{array}{c}108- \\
660\end{array}$ & $\begin{array}{c}90- \\
890\end{array}$ & $54-680$ & $60-865$ & $\begin{array}{c}45- \\
1245\end{array}$ & $\begin{array}{l}100- \\
1240\end{array}$ & $\begin{array}{l}90- \\
1040\end{array}$ & $\begin{array}{c}80- \\
1135\end{array}$ & $\begin{array}{c}49- \\
1137\end{array}$ & $\begin{array}{c}56- \\
1145\end{array}$ & $\begin{array}{l}65- \\
950\end{array}$ \\
\hline Zinc & $8.0-62$ & $12-72$ & $1.9-48$ & $4.6-87$ & $4.9-82$ & $13-80$ & $10-80$ & $7.6-73$ & $6.7-89$ & $6.2-68$ & $7.8-90$ \\
\hline Chromium & $12-62$ & 18-82 & $10-83$ & 9.8-86 & $7.9-79$ & $11-104$ & $11-84$ & 6.3-81 & $6.0-80$ & |7.7-114 & $6.4-80$ \\
\hline Copper & $10-39$ & $11-34$ & 12-38 & $9.7-38$ & $11-43$ & $12-42$ & $9.2-40$ & $10-37$ & $9.3-39$ & 9.4-36 & $10-45$ \\
\hline Lead & $1.2-26$ & $1.9-27$ & $2.0-26$ & $\mid$ & $1.6-36$ & |2.8-18 & $1.7-26$ & $4.2-18$ & 2.7-30 & $\mid 1.4-17$ & 3.0-19 \\
\hline
\end{tabular}

Continuation of Table 1

\begin{tabular}{l|c|c|c|c|c|c|c|c|c|c|c}
\hline \multirow{2}{*}{ Metal } & \multicolumn{7}{|c|}{ Content in bottom sediments } & $\begin{array}{c}\text { Content } \\
\text { in the } \\
\text { Earth } \\
\text { crust } \\
{[8]}\end{array}$ \\
\hline & 2011 & 2012 & 2013 & 2014 & 2015 & 2016 & 2017 & 2018 & 2019 & 2020 \\
\hline Iron & $1515-$ & $2425-$ & $3660-$ & $3850-$ & $1868-$ & $5536-$ & $4066-$ & $4074-$ & $4564-$ & $5386-$ & 46500 \\
& 38120 & 39516 & 41710 & 49902 & 40334 & 39557 & 37735 & 38800 & 42035 & 40077 & 46500 \\
\hline Manganese & $40-$ & $100-$ & $84-$ & $73-$ & $65-$ & $61-$ & $80-$ & $57-$ & $50-$ & $105-$ & 1000 \\
& 1190 & 1211 & 1194 & 1230 & 1304 & 1229 & 1244 & 1157 & 1324 & 1326 & 10 \\
\hline Zinc & $4.4-69$ & $4.2-84$ & $9.5-88$ & $10-103$ & $4.1-84$ & $8.9-94$ & $6.2-98$ & $11-396$ & $\begin{array}{c}14- \\
105\end{array}$ & $16-89$ & 83 \\
\hline Chromium & $5.1-91$ & $7.3-$ & $8.9-95$ & $7.0-$ & $5.5-$ & $17-$ & $19-$ & $11-177$ & $17-$ & $10-116$ & 83 \\
\hline Copper & $8.6-98$ & $10-38$ & $11-46$ & $10-46$ & $9.2-43$ & $10-43$ & $8.9-46$ & $9.0-33$ & $10-32$ & $5.4-40$ & 47 \\
\hline Lead & $<1.0-$ & $<1.0-$ & $3.1-23$ & $2.9-33$ & $3.3-22$ & $2.3-20$ & $1.9-23$ & $2.7-21$ & $6.3-24$ & $6.9-19$ & 16 \\
\hline
\end{tabular}

During almost the entire observation period, the concentration of iron in the bottom sediments of the studied water area was, on average, within the range of $17000-29000 \mathrm{mg} / \mathrm{kg}$ dry weight. The relative minimum (1479 mg/kg) was noted in 2003, the maximum (up to $49902 \mathrm{mg} / \mathrm{kg}$ ) - in the spring-early summer period of 2001 and 2013 in the Kerch pre-strait (perhaps this is due to the hydrodynamics). On the whole, no significant fluctuations in the difference in seasonal and interannual iron accumulation were revealed, and a positive trend is not obvious (Fig. 2). The average annual maximum (the ratio of seasonal to average annual accumulation reaches 1.4) was observed at the exit from the Tsemess Bay, which is probably determined by the anthropogenic contribution. 

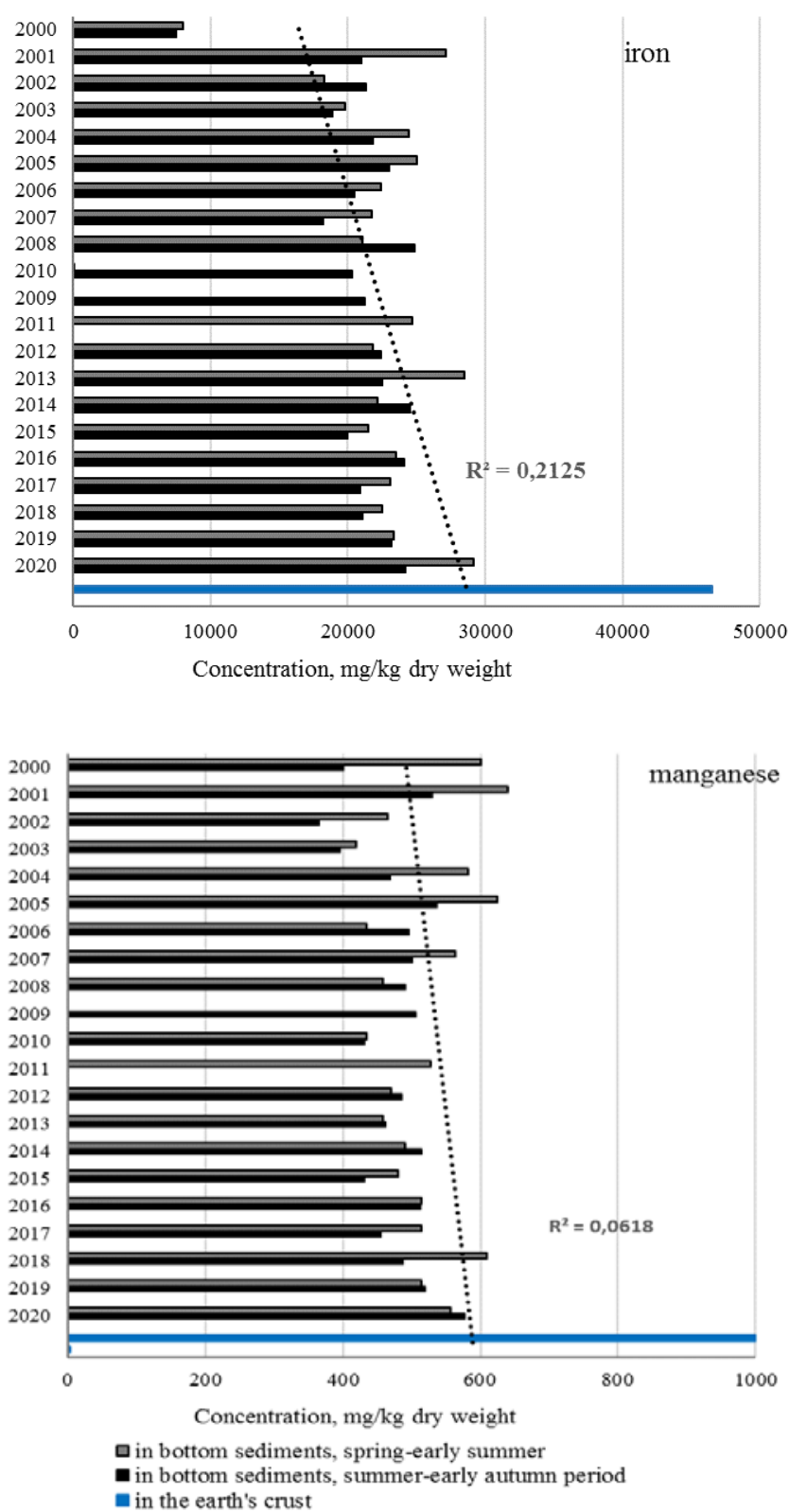

F i g. 2. Iron and manganese average content in the bottom sediments of the Black Sea northeastern shelf by seasons, 2000-2020 (the dotted line shows the content trend)

The manganese content in bottom sediments during the entire observation period changed very little (Table 1), mainly some insignificant fluctuations were observed (the minimum - in 2003, the maximum - in 2001 and 2005). The concentrations were similar: $490 \mathrm{mg} / \mathrm{kg}$ in the spring-early summer period and $470 \mathrm{mg} / \mathrm{kg}$ dry weight in the summer-early autumn period. The tendency for an increase in the manganese content in bottom sediments from the beginning of the observation period to 2020 is almost not pronounced (Fig. 2). 


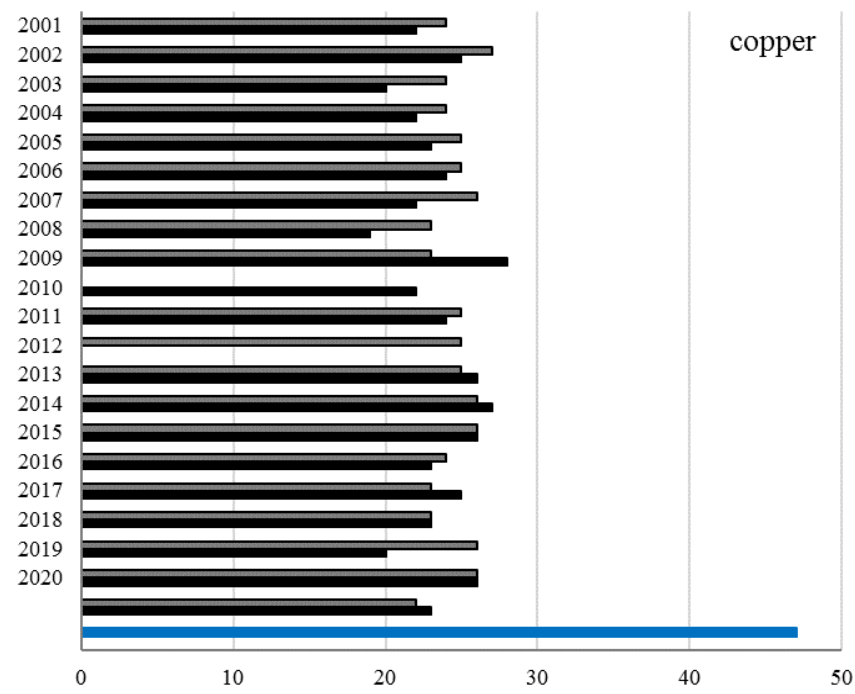

Concentration, $\mathrm{mg} / \mathrm{kg}$ dry weight

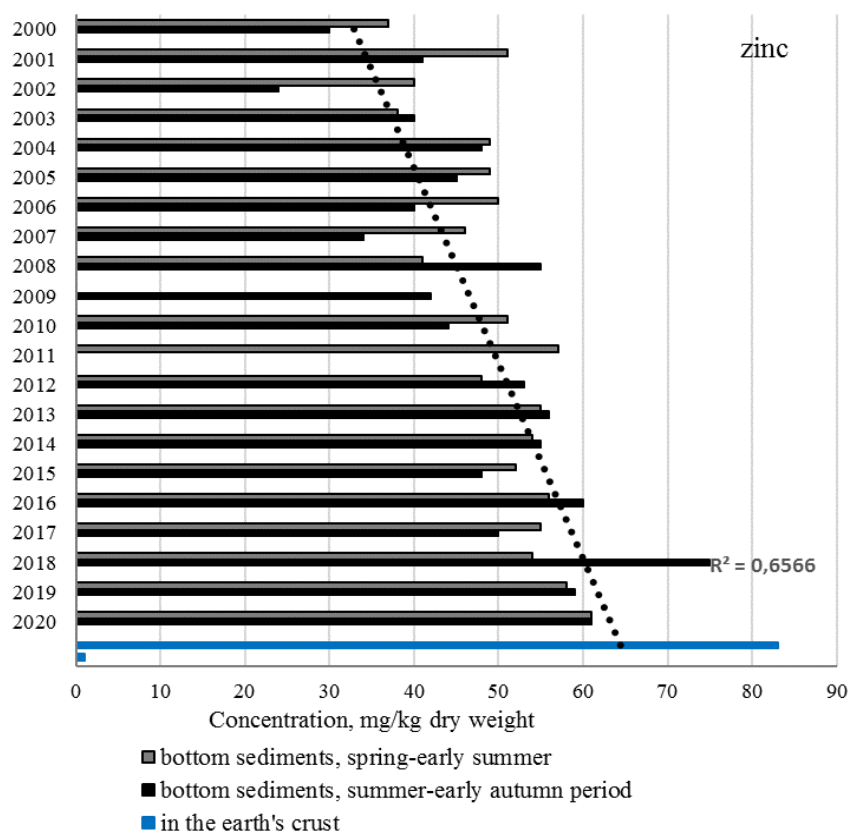

F i g. 3. Copper and zinc average content in the bottom sediments of the Black Sea northeastern shelf by seasons, 2000-2020 (the dotted line shows the content trend)

The copper content in the shelf bottom sediments on average in both seasons was within a narrow range of $23-25 \mathrm{mg} / \mathrm{kg}$ dry weight. The minimum $(19 \mathrm{mg} / \mathrm{kg}$ dry weight) and the maximum (28 $\mathrm{mg} / \mathrm{kg}$ dry weight) concentrations were observed in the summer-early autumn period of 2007 and 2008, respectively. Differences in seasonal and inter-annual copper accumulation during the last 
20 years of observations on the surveyed bottom area were not revealed (Fig. 3). The copper content averaged over the entire observation period in the bottom sediments of the Kerch pre-strait, at the exit from the Tsemess Bay and in Greater Sochi area was 19, 30, and $26 \mathrm{mg} / \mathrm{kg}$ dry weight in the spring-early summer period, in the summer-early autumn period - 18, 28 and $25 \mathrm{mg} / \mathrm{kg}$ dry weight, respectively. There is no seasonal variability of the copper content both in the above-considered and in other areas of the surveyed water area. A significant average annual maximum (the ratio of seasonal to average annual content reaches 1.6) is noted at the exit from the bay.

A certain stability of the situation is explained by the peculiarities of the diagenesis of the Black Sea bottom sediments, the types and phases of which are directly related to the physicochemical processes occurring in the basin and the activity of a number of microorganisms (for example, iron bacteria) [9]. In addition, in the upper $0-2 \mathrm{~cm}$ layer of bottom sediments, the main material is organic matter, which has a high sorption capacity. Metals biologically significant for aquatic organisms (iron, manganese) are consumed in large quantities from the water by plants during the growing season, and then deposited in bottom sediments in dead remains.

It is known that the main sources of zinc input into the basin are parent rocks and runoff from territories subject to anthropogenic pollution, additional atmospheric precipitation (through aerosols, dust) (see thesis ${ }^{1}$ and work [10]). According to the performed studies, higher concentrations of zinc were found in the bottom sediments in the areas located as close as possible to the coastline (up to $80 \mathrm{mg} / \mathrm{kg}$ dry weight at the exit from the Tsemess Bay). In the absence of seasonal variability in each of the three areas under consideration, an average annual maximum of this metal content at the exit from the bays takes place. On the whole, over the shelf from 2000 to 2020, there is a tendency of a gradual increase in the zinc content in the bottom sediments of the surveyed water area (approximately 1.6 times), which obviously reflects the process of the anthropogenic load increase on the adjacent territories (Fig. 3).

For chromium, the situation turned out to be similar, since catchment soils are an important source of pollution of the coastal sea area with this metal. During almost the entire observation period, its concentration in the shelf bottom sediments was, on average, $48-58 \mathrm{mg} / \mathrm{kg}$ dry weight. Against the background of close annual average indicators, the indicators of 2002 and 2018 stand out, when the chromium concentration in the spring-early summer period turned out to be 1.8 and 1.5 times higher than in summer and early autumn, respectively, due to removal from the Tsemess Bay. In addition, in the spring-early summer period 2000, 2001, 2005, 2011 and 2016-2018 the content of chromium in the shelf bottom sediments, on average, exceeded its content in the Earth's crust due to the increased content on the traverses of Cape Zhelezny Rog, Tsemess and Gelendzhik bays. On the whole, for chromium (as well as for zinc), a tendency for the content to increase from the beginning of the observation period to 2020 approximately twofold was noted (Fig. 4).

\footnotetext{
${ }^{1}$ Alekseenko, A.V., 2018. Assessment and Reduction of the Environmental Hazard of Mining Dumps in the Novorossiysk Industrial Agglomeration. Ph.D. thesis. St. Petersburg, 178 p. (in Russian).
} 

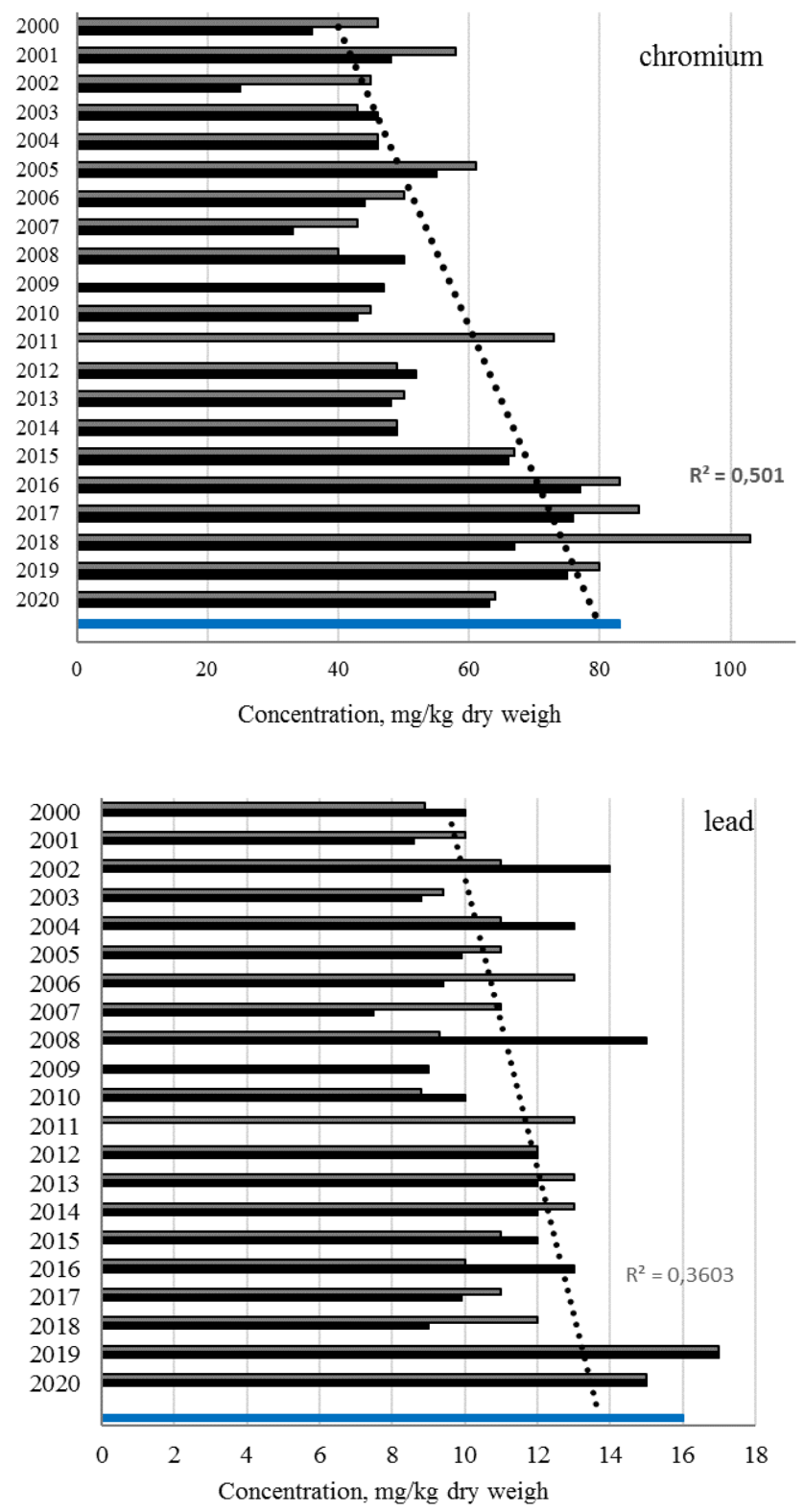

口bottom sediments, spring-early summer

- bottom sediments, summer-early autumn period

n in the earth's crust

F i g. 4. Chromium and lead average content in the bottom sediments of the Black Sea northeastern shelf by seasons, 2000-2020 (the dotted line shows the content trend)

The lead content in shelf bottom sediments of the Black Sea northeastern part in both observation seasons in all years (except for 2008) was within the range of $8.5-13 \mathrm{mg} / \mathrm{kg}$ dry weight with a minimum $(7.5 \mathrm{mg} / \mathrm{kg})$ and maximum $(17 \mathrm{mg} / \mathrm{kg})$ indicators in the summer-early autumn period of 2007 and 2019, respectively. Moreover, in 2019, for the first time since the beginning of observations, 
the average lead content exceeded its content in the Earth's crust (Fig. 4). The maximum indicators in all cases are observed abeam the mouth of the Mzymta River and Tsemess bay, capes Zhelezny Rog and Panagia. Presumably, lead is concentrated in the bottom sediments as a result of transition from suspended matter to water. With the content of suspended matter in the Black Sea water in the Greater Sochi area on average at $1960-2630 \mu \mathrm{g} / \mathrm{dm}^{3}$ level, the lead concentration ranges from 3.7-14.3 $\mu \mathrm{g} / \mathrm{dm}^{3}$ [11]. High wave activity increases the content of its suspended forms, thereby increasing the dissolved part in the bottom sediments, in which the content of the mobile form available to organisms can reach $45 \%$ of the total content [12]. Another source of accumulation is bottom sediments with high organic matter content (Greater Sochi area).

On average, from the beginning of the observation period to 2020, the lead content in bottom sediments changed little (by about 20\%).

The studies carried out by a number of authors demonstrate that the background concentrations of heavy metals in the Black Sea bottom sediments differ significantly (Table 2) and significantly depend on the area, the observation period, and especially on distribution [4, 13-16]. Therefore, it seems unreasonable to take this value as a comparison standard.

Table 2

Content of heavy metals in the Black Sea bottom sediments, $\mathrm{mg} / \mathrm{kg}$ dry weight, based on various sources

\begin{tabular}{l|c|c|c}
\hline \multirow{2}{*}{ Element } & \multicolumn{2}{|c|}{ Data from scientific literature } & Data of the AzNIIRKH, 2000-2020 \\
& \multirow{2}{*}{ Shelf [4, 13] } & Deep water area [4] & Shelf \\
\cline { 2 - 3 } & $5080-26600$ & $32900-51600$ & $1479-49902$ \\
\cline { 1 - 1 } Iron & $380-679$ & $470-950$ & $40-1326$ \\
\cline { 1 - 1 } Manganese & $48-120$ & $32-240$ & $4.1-396$ \\
Zinc & $20-90$ & $15-100$ & $5.1-177$ \\
\cline { 1 - 1 } Chromium & $31-38$ & $36-121$ & $5.4-98$ \\
\cline { 1 - 1 } Copper & 16 & 35 & $<1.0-36$ \\
\hline Lead &
\end{tabular}

The granulometric composition of bottom sediments on the shelf of the Black Sea northeastern part is heterogeneous: from coarse sandy shell fractions to finely dispersed silts. The latter are concentrated mainly in the area between Cape Kadosh and the mouth of the Mzymta River. Naturally, due to the better sorption capacity the silts always contain large amounts of metals. During the entire period of research on this section of the sea bottom, the absolute contamination of bottom sediments with most of the monitored metals is the highest. However, there are no large industrial enterprises and ports with a significant volume of cargo 
transshipment in the adjacent territory. The largest impact on the region's ecosystem is associated with the construction and operation of Olympic facilities, i.e. it actually began in 2010. The impact factors were the laying of access roads and underground communications to the construction sites and the construction of the combined (road and rail) road between Adler and “Alpika-Service”. Negative impact was exerted by the work associated with the area clearing, the production of various stripping works on the coastal sections of the Mzymta River with the slopes of more than $20^{\circ}$ (occurrence of landslides and mudflows). In addition, Krasnopolyanskaya HPP is operated in the mountain cluster. The load on the existing sewage treatment facilities in the Central and Adler districts of Sochi has increased many times over. Average annual concentration of chromium, zinc and copper in bottom sediments of Greater Sochi from 2000-2009 to 2010-2020 increased by $\sim 20 \%$, but a simple statement of the bottom sediments absolute pollution does not always reflect the real state of the basin.

In order to substantiate the introduction of a generalizing indicator for assessing the quality of bottom sediments in the Black Sea northeastern part, their typification was carried out according to the granulometric composition. There are many examples of such a typification. Depending on the approach, the number of identified types varies from 4 to 20 [17-19]. In the modern period, for certain water areas of the Black Sea (mainly the Crimean Peninsula), the typification of bottom sediments for applied purposes is used by the specialists of Marine Hydrophysical Institute of RAS [13, 20-22]. According to the studies carried out by specialists of the Azov-Black Sea branch of FSBSI “VNIRO” (“AzNIIRKH”) in the northeastern part of the Black Sea, four most common types of bottom sediments, determined on the basis of typification by external distinctive features, were identified. It includes preliminary systematization of the soil in a wet state (the predominant soil component is estimated: shell rock, sand, silt) and after drying, when a thinner soil structure appears against the background of silt (sand or shell rock) and the silts acquire a characteristic color and density, etc., as well as the determination of the correlation dependence of the content of some metals on the lithological types of bottom sediments [23]. The assessment of shell rock proportion in the composition of bottom sediments was linked to the strontium content. With a decrease in the shell rock proportion, the strontium content decreases, and the content of other elements rises due to an increase in the silty component proportion and, consequently, the sorption capacity of bottom sediments. The estimation of the clay component proportion was linked to the content of iron and aluminum, as well as vanadium and nickel, which have similar chemical properties.

Analysis of retrospective data on the content of metals in the bottom sediments of the Black Sea northeastern waters provided the determination of their typical priority in terms occurrence frequency. In 2000-2020, in the surveyed sea area the silts were most common (Table 3). 


\section{Content of heavy metals in various types of bottom sediments on the Black Sea northeastern shelf}

\begin{tabular}{l|c|c|c|c|c|c}
\hline \multirow{2}{*}{ Bottom sediments type } & \multicolumn{2}{|c|}{ Content in bottom sediments, mg/kg dry weight } & \multirow{2}{*}{$\begin{array}{c}\text { Frequency of } \\
\text { occurrence, \% }\end{array}$} \\
\cline { 2 - 6 } & strontium & aluminum & iron & nickel & vanadium & \\
\hline $\begin{array}{l}\text { Shell rock, shell crumb } \\
\text { with sand admixture } \\
(>10-1 \mathrm{~mm})\end{array}$ & $690-1350$ & $\begin{array}{c}10000- \\
30000\end{array}$ & $\begin{array}{c}2000- \\
9000\end{array}$ & $16-19$ & $10-25$ & 25 \\
\hline $\begin{array}{l}\text { Sand with shell crumb and } \\
\text { silt admixture }(<1-0.1 \mathrm{~mm})\end{array}$ & $380-700$ & $\begin{array}{c}29000- \\
49000\end{array}$ & $\begin{array}{c}8500- \\
19000\end{array}$ & $18-45$ & $24-45$ & 23 \\
\hline $\begin{array}{l}\text { Silty fine sand with shell } \\
\begin{array}{l}\text { crumb admixture } \\
(<0.1-0.05 \mathrm{~mm})\end{array}\end{array}$ & $280-390$ & $\begin{array}{c}48000- \\
59000\end{array}$ & $\begin{array}{c}18000- \\
29000\end{array}$ & $44-55$ & $44-75$ & 20 \\
\hline $\begin{array}{l}\text { Fine silt and pelitic silts } \\
(<0.05-0.001 \mathrm{~mm})\end{array}$ & $200-290$ & $\begin{array}{c}58000- \\
69000\end{array}$ & $\begin{array}{c}28000- \\
39000\end{array}$ & $54-65$ & $74-95$ & 2 \\
\hline
\end{tabular}

Within the boundaries of the studied water area, various types of bottom sediments are unevenly distributed over the bottom area. In the surface layer of $0-2 \mathrm{~cm}$ at the same station the granulometric composition of bottom sediments can differ not only from year to year, but also from season to season (Fig. 5). This process is largely due to hydrological factors. However, what for the hydrochemical factors, the amount of organic matter and the rate of its decay are of great importance. With intensive redox processes in the sediment layer, the upper oxidized layer usually does not exceed $1 \mathrm{~cm}$. At a relatively low $\mathrm{C}_{\text {org }}$ content the reduction processes are poorly developed and the oxidized layer can have a significant thickness - up to several meters [11].

Consequently, the correct estimation of the bottom sediments pollution, the identification of increased anthropogenic impact sources are possible only when leveling the differences associated with the composition of bottom sediments [23, 24]. For this purpose, it is necessary to introduce the concept of the average characteristic concentration (ACC). In order to calculate the ACC of individual elements, the results of the analysis of more than 600 samples of bottom sediments obtained in different seasons of 2000-2020 were used. The sample size was determined by the statistical power, which is the probability that the expected result will be obtained for the selected size. The widespread threshold is $80 \%$ [25]. Consequently, for each type of bottom sediments, the results of the analysis of $20 \%$ of the data, in which the concentration of a particular metal had the minimum and maximum concentrations, were excluded from the data set. The average concentration value of each of the metals from the remaining analysis results was taken as characteristic for this type of bottom sediments (Table 4). (A similar approach was developed by the Azov-Black Sea branch of "VNIRO" (“AzNIIRKH”) for the Sea of Azov, where it has proven itself well [24].) 


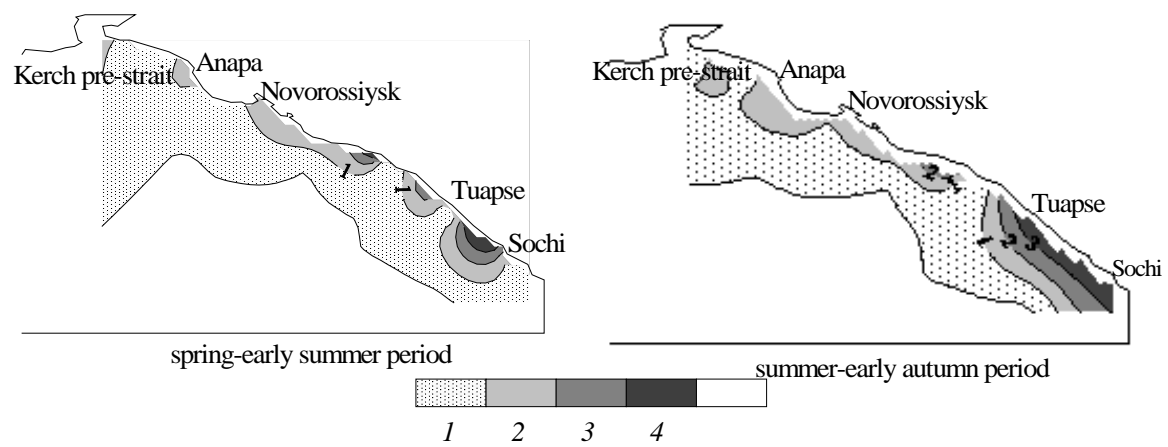

F i g. 5. Spatial distribution of the bottom sediments types on the Black Sea northeastern shelf in 2019: 1 - shell rock, shell crumb with sand admixture ( $>10-1 \mathrm{~mm}) ; 2$ - sand with shell crumb and silt admixture (<1-0.1 mm); 3 - silty fine sand with shell crumb admixture $(<0.1-0.05 \mathrm{~mm})$; $4-$ fine silt and pelitic silts $(<0.05-0.001 \mathrm{~mm})$

The relation of the found concentration of an element to its ACC value in the corresponding type of bottom sediments provides a dimensionless value the multiple of the ACC excess:

$$
\text { The multiplicity of excess of } A C C=\frac{C i}{A C C}
$$

where $C_{i}$ is obtained concentration of the determined $i$-metal; ACC - is average characteristic concentration of $i$-metal in the corresponding type of bottom sediments.

The multiplicity of the ACC excess characterizes the pollution degree of a given area (taking into account the granulometric composition of sediments) by an individual metal (possibly a group of metals) in a specific period of time. In case when the multiplicity of the ACC excess $\leq 1.0$, it can be assumed that in this area, regardless of the absolute pollution values, there was practically no fresh supply of the metal being determined. With a multiplicity of the ACC excess $\geq 1.2$, it can be considered that this area is an area of increased anthropogenic impact in a specific period of time and requires a more detailed study to determine the pollution source.

T a ble 4

Average characteristic concentrations of heavy metals, $\mathrm{mg} / \mathrm{kg}$ dry weight, in various types of bottom sediments of the Black Sea northeastern shelf

\begin{tabular}{l|c|c|c|c|c|c}
\hline $\begin{array}{l}\text { Granulometric type of bottom } \\
\text { Sediments }\end{array}$ & Iron & Manganese & Zinc & Chromium & Copper & Lead \\
\hline $\begin{array}{l}\text { Shell rock, shell crumb with } \\
\text { sand admixture (> } 10-1 \mathrm{~mm})\end{array}$ & 9000 & 243 & 17 & 28 & 14 & 5.8 \\
\hline $\begin{array}{l}\text { Sand with shell crumb and silt } \\
\text { admixture (<1-0.1 mm) }\end{array}$ & 19900 & 469 & 42 & 55 & 24 & 11 \\
\hline $\begin{array}{l}\text { Silty fine sand with shell crumb } \\
\text { admixture (<0.1-0.05 mm) }\end{array}$ & 26900 & 543 & 63 & 60 & 32 & 16 \\
\hline $\begin{array}{l}\text { Fine silt and pelitic silts } \\
(<0.05-0.001 \mathrm{~mm})\end{array}$ & 36900 & 845 & 75 & 73 & 35 & 18 \\
\hline
\end{tabular}


The mapping of the obtained data provided the confident identification of the areas where the values of the multiplicity of the ACC excess of a number of metals are systematically equal to or exceed 1.2 , which may indicate the presence of a constant source of their entry into the basin. From 2000 to 2020, the ACC excess by 1.2 times or more was noted for all monitored elements, except for iron. An excess of the manganese ACC by 1.2-1.6 times was recorded in 6 cases (2005, 2010, 2012, 2014, 2020) with the maximum indicators in the summer-early autumn period of 2010; zinc by 1.2 times - in 6 cases (2013, 2015-2017, 2019, 2020); chromium by 1.2-2.2 times - in 10 cases (2010, 2015-2019) with maximum indicators in the spring-early summer period of 2019 (the absolute maximum among all elements). The ACC excess of copper by 1.2 and 1.3 times was observed in the summer-early autumn period of 2014 and 2018, respectively. For lead, 6 cases of the ACC excess by 1.2-1.6 times (2015-2016, 2019-2020) with the maximum indicators in the summer-early autumn period of 2016 (Tables 5, 6) were recorded. The detection of elevated concentrations of one or another metal in some years of observations is obviously associated with local cases of anthropogenic pollution and is geographically linked to more industrialized coastal areas (ports).

Table 5

Multiplicity of excess of the heavy metals average characteristic concentrations in the bottom sediments of the Black Sea northeastern shelf in spring-early summer, 2000-2020

\begin{tabular}{c|c|c|c|c|c|c|c}
\hline Year & Iron & Manganese & Zinc & Chromium & Copper & Lead & $\begin{array}{l}\text { Average multiplicity } \Sigma \\
\text { of the ACC excess }\end{array}$ \\
\hline 2000 & 0.96 & 1.00 & 0.90 & 0.94 & 1.00 & 1.10 & 0.98 \\
\hline 2001 & 0.89 & 0.88 & 0.84 & 0.82 & 1.00 & 0.99 & 0.90 \\
\hline 2002 & 0.97 & 0.91 & 0.93 & 0.83 & 0.99 & 1.10 & 0.96 \\
\hline 2003 & 1.10 & 0.98 & 0.83 & 1.10 & 0.85 & 0.67 & 0.92 \\
\hline 2004 & 1.00 & 1.10 & 1.00 & 1.10 & 0.98 & 0.86 & 1.00 \\
\hline 2005 & 1.10 & $\mathbf{1 . 2 0}$ & 0.96 & 1.10 & 0.99 & 0.86 & 1.00 \\
\hline 2006 & 0.96 & 0.85 & 1.00 & 0.88 & 0.99 & 1.00 & 0.95 \\
\hline 2007 & 0.89 & 1.10 & 0.87 & 0.68 & 0.84 & 0.81 & 0.87 \\
\hline 2008 & 0.84 & 0.89 & 0.89 & 0.78 & 0.91 & 0.85 & 0.86 \\
\hline 2010 & 1.00 & $\mathbf{1 . 5 0}$ & 0.81 & $\mathbf{1 . 2 0}$ & 0.71 & 0.41 & 0.94 \\
\hline 2011 & 0.92 & 1.10 & 0.93 & 0.90 & 0.83 & 0.66 & 0.89 \\
\hline 2012 & 0.97 & $\mathbf{1 . 3 0}$ & 0.93 & 1.10 & 0.80 & 0.61 & 0.95 \\
\hline 2013 & 1.00 & 1.00 & $\mathbf{1 . 2 0}$ & 0.90 & 1.00 & 1.10 & 1.00 \\
\hline 2014 & 0.94 & $\mathbf{1 . 2 0}$ & 0.84 & 0.82 & 0.87 & 0.68 & 0.89 \\
\hline 2015 & 0.96 & 0.92 & 0.82 & 0.85 & 0.90 & $\mathbf{1 . 2 0}$ & 0.94 \\
\hline 2016 & 0.94 & 0.86 & 1.10 & $\mathbf{1 . 4 0}$ & 0.94 & 0.92 & 1.00 \\
\hline 2017 & 0.86 & 0.91 & 1.00 & $\mathbf{1 . 3 0}$ & 0.85 & 0.84 & 0.96 \\
\hline 2018 & 0.92 & 0.93 & 1.10 & $\mathbf{1 . 9 0}$ & 0.98 & 1.00 & 1.10 \\
\hline 2019 & 1.00 & 0.58 & $\mathbf{1 . 2 0}$ & $\mathbf{2 . 2 0}$ & 1.10 & $\mathbf{1 . 2 0}$ & $\mathbf{1 . 2 0}$ \\
\hline 2020 & 0.96 & $\mathbf{1 . 2 0}$ & 0.94 & 1.10 & 0.86 & $\mathbf{1 . 3 0}$ & 1.10 \\
\hline PHYSICAL OCEANOGRAPHY VOL. 28 & ISS.5 & $(2021)$ & & 561 \\
\hline
\end{tabular}


Multiplicity of excess of the heavy metals average characteristic concentrations in the bottom sediments of the Black Sea northeastern shelf in summer-early autumn, 2000-2020

\begin{tabular}{|c|c|c|c|c|c|c|c|}
\hline Year & Iron & Manganese & Zinc & Chromium & Copper & Lead & $\begin{array}{l}\text { Average multiplicity } \\
\Sigma \text { of the ACC excess }\end{array}$ \\
\hline 2000 & 0.98 & 0.96 & 0.96 & 0.81 & 1.00 & 1.10 & 0.97 \\
\hline 2001 & 0.85 & 0.88 & 0.86 & 0.85 & 1.00 & 1.00 & 0.91 \\
\hline 2002 & 0.86 & 0.82 & 0.95 & 0.80 & 0.94 & 0.95 & 0.89 \\
\hline 2003 & 0.88 & 0.82 & 0.88 & 0.91 & 0.92 & 0.74 & 0.86 \\
\hline 2004 & 0.97 & 0.92 & 0.97 & 0.92 & 0.99 & 0.97 & 0.96 \\
\hline 2005 & 0.95 & 0.95 & 0.95 & 0.82 & 1.00 & 1.00 & 0.95 \\
\hline 2006 & 0.79 & 0.81 & 0.86 & 1.10 & 0.85 & 1.00 & 0.90 \\
\hline 2007 & 0.84 & 1.00 & 0.77 & 0.61 & 0.80 & 0.71 & 0.79 \\
\hline 2008 & 0.87 & 0.83 & 0.96 & 0.81 & 0.95 & 0.96 & 0.90 \\
\hline 2009 & 0.96 & 1.00 & 0.91 & 0.87 & 0.90 & 0.75 & 0.90 \\
\hline 2010 & 1.00 & 1.60 & 0.88 & 1.30 & 0.83 & 0.42 & 1.00 \\
\hline 2012 & 0.93 & 0.94 & 0.87 & 0.83 & 0.87 & 0.74 & 0.86 \\
\hline 2013 & 0.91 & 0.86 & 1.10 & 0.84 & 1.00 & 1.00 & 0.95 \\
\hline 2014 & 1.00 & 0.85 & 1.00 & 0.82 & 1.20 & 0.80 & 0.95 \\
\hline 2015 & 1.10 & 0.92 & 1.20 & 1.30 & 0.98 & 1.10 & 1.10 \\
\hline 2016 & 1.10 & 0.68 & 1.20 & 1.30 & 1.00 & 1.90 & 1.20 \\
\hline 2017 & 0.99 & 0.91 & 1.20 & 1.50 & 1.00 & 0.91 & 1.10 \\
\hline 2018 & 1.00 & 0.85 & 1.00 & 0.82 & 1.30 & 0.80 & 0.96 \\
\hline 2019 & 0.96 & 0.94 & 1.20 & 1.40 & 1.00 & 1.60 & 1.20 \\
\hline 2020 & 0.85 & 1.00 & 1.20 & 1.10 & 0.79 & 1.40 & 1.10 \\
\hline
\end{tabular}

This approach is also applicable in estimating the total pollution of bottom sediments with heavy metals. In the summer-early autumn period of 2016 and in both observation seasons of 2019, the relative total content of metals exceeded the ACC by 1.2 times, which is probably due to the anthropogenic input of zinc, chromium and lead (the maxima are linked to the traverses of the Zhelezny Horn and Tsemess Bay, Greater Sochi area). In other years, in other areas of the surveyed water area, the total pollution with heavy metals was not increased and was at 0.79-1.1 ACC level (Tables 5, 6).

According to the data averaged over the past 20 years of observations in the Black Sea northeastern waters, the most problematic areas subject to increased anthropogenic load can be identified: in both seasons - the Kerch pre-strait, traverses of the Abrau Peninsula, Tsemess and Gelendzhik bays, in the spring-early 
summer period - also the bottom areas abeam the mouths of the Vulan, Psezuapse, Shakhe, Dagomys Zapadny, Sochi, and Mzymta rivers (Fig. 6).

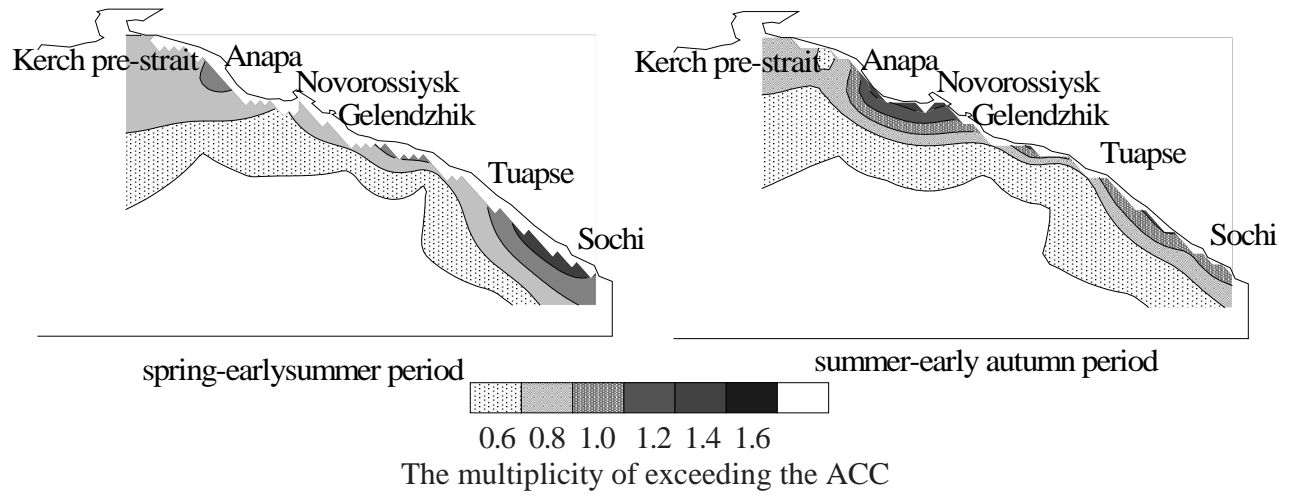

F i g. 6. Average distribution of heavy metal pollution in the bottom sediments of the Black Sea northeastern shelf in 2000-2020 (by the multiplicity of excess of the average characteristic concentration)

\section{Conclusion}

Long-term observations of the heavy metals content in bottom sediments of the Black Sea northeastern part made it possible to reveal some regularities of their accumulation: from the beginning of the observation period (2000) to 2020, an increase in the average long-term concentration of lead by 1.2 times, zinc - by 1.6 times, chromium - by 2 times was noted. The content of iron, manganese and copper has remained practically unchanged over the past 20 years. The observed fluctuations can be caused by river runoff and local anthropogenic sources located on the coast (ports, cities and large settlements).

Interpretation of data on the heavy metals content in the bottom sediments, taking into account the type of soil and the corresponding ACC, showed that in the period from 2000 to 2020 there were cases of its excess. The maximum frequency of the ACC excess and the largest number of excess cases were revealed for chromium, the territorial reference - the traverse of Cape Zhelezny Rog and the Tsemess Bay - indirectly indicates an anthropogenic source of its input.

When estimating the total pollution of bottom sediments of the Black Sea northeastern part with heavy metals in 2000-2020, the regions in which the multiplicity of the ACC sum for a longer period of time was more than 1 were identified (Kerch pre-strait, outlets from the Tsemesskaya and Gelendzhik bays, traverses of the Abrau Peninsula, the mouths of the Vulan, Psezuapse, Shakhe, Dagomys Zapadny, Sochi, Mzymta rivers). In the temporal section, the most polluted were the bottom sediments sampled in 2019: in both observation seasons, the excess of the background values reached 1.2 ACC. The cause is an increase in the total anthropogenic load. Thus, the turnover of only the port of Novorossiysk in 2019 increased (compared to 2018) by $7.8 \%$, and in 2020, a decrease by $21.9 \%$ (compared to 2019) was noted. 


\section{REFERENCES}

1. Tikhonova, E., Kotelyanets, E. and Soloveva, O., 2016. Evaluation of the Contamination Level of Sea Bottom Sediments on the Crimean Coast of the Black and Azov Seas. Principles of the Ecology, (5), pp. 56-70. doi:10.15393/j1.art.2016.5283 (in Russian).

2. Minkina, T.M., Fedorov, Yu.A., Nevidomskaya, D.G., Pol'shina, T.N., Mandzhieva, S.S. and Chaplygin, V.A., 2017. Heavy Metals in Soils and Plants of the Don River Estuary and the Taganrog Bay Coast. Eurasian Soil Science, 50(9). pp. 1033-1047. https://doi.org/10.1134/S1064229317070067

3. Gurov, K. and Kotelyanets, E., 2018. Estimation of the Trace Metals Accumulation in Bottom Sediments and Their Connection with the Granulometric Composition. In: SGEM, 2018. 18th International Multidisciplinary Scientific GeoConference SGEM 2018: proceedings. Sofia: STEF92 Technology Ltd. Vol. 18, book 3.2, pp. 1127-1134. doi:10.5593/sgem2018/3.2/S15.143

4. Mitropol'skii, A.Yu., Bezborodov, A.A. and Ovsyanyi, E.I., 1982. Geochemistry of the Black Sea. Kiev: Nauka, 144 p. (in Russian).

5. Khristoforova, N.K., 1989. Bioindication and Monitoring of Marine Water Pollution by Heavy Metals. Leningrad: Nauka, 192 p. (in Russian).

6. Barabashin, T.O., ed., 2018. Methods for Measuring the Mass Fractions of Aluminum, Barium, Vanadium, Iron, Cobalt, Magnesium, Manganese, Copper, Arsenic, Nickel, Lead, Strontium, Titanium, Chromium, Zinc and Sulfur in Soil and Bottom Sediment Samples of Fresh and Marine Water Bodies Using X-Ray Fluorescence Analysis. In: T. O. Barabashin, Ed., 2018. A Practical Guide to the Chemical Analysis of Elements of Aquatic Ecosystems. Priority Toxicants in Water, Bottom Sediments, Aquatic Organisms. Rostov-on-Don: Mini Tipe, pp. 46-60 (in Russian).

7. Barabashin, T.O., Korablina, I.V., Pavlenko, L.F., Skrypnik, G.V. and Korotkova, L.I., 2018. Methodological Support of Pollution Monitoring of the Azov and Black Seas Water Bodies. Aquatic Bioresources \& Environment, 1(3-4), pp. 9-27. doi:10.47921/26191024_2018_1_3-4_9

8. Vinogradov, A.P., 1989. Ocean Geochemistry. Moscow: Nauka, 220 p. (in Russian).

9. Novikov, M.A. and Zhilin, A.Yu., 2016. Distribution of Heavy Metals in Bottom Sediments of the Barents Sea Based on the Results of Statistical Analysis. Bulletin of Kamchatka Regional Association “Educational-Scientific Center”. Earth Sciences, 29(1), pp. 78-88 (in Russian).

10. Korshenko, A., Ed., 2016. Marine Water Pollution. Annual Report 2015. Moscow: Nauka, 184 p. (in Russian).

11. Papina, T.S., 2001. Transport and Peculiarities of Heavy Metals Distribution in the Row: Water - Suspended Substance - River Ecosystems Sludge. Novosibirsk, 2001. 58 p. (in Russian).

12. Barabashin, T.O., Korablina, I.V., Pavlenko, L.F., Skrypnik, G.V., Bogachev, A.N. and Belousov, V.N., 2020. Content of Toxic Substances in the Deep-Sea and Coastal Areas of the Black Sea off the Crimean Peninsula in Spring-Autumn, 2019. In: VNIRO, 2020. Trudy VNIRO, 181, pp. 187-205. doi:10.36038/2307-3497-2020-181-187-205

13. Emel'yanov, V.A., Mitropol'skij, A.Yu., Nasedkin, E.I., Pasynkov, A.A., Stepanyak, Yu.D. and Shnyukova, E.E., 2004. Geoecology of the Ukrainian Black Sea Shelf. Kiev: Akademperiodika, 293 p. (in Russian).

14. Kotelyanets, E.A. and Konovalov, S.K., 2008. Distribution of Heavy Metals in Bottom Sediments of Feodosiya Bay. In: MHI, 2008. Ekologicheskaya Bezopasnost' Pribrezhnykh $i$ Shel'fovykh Zon i Kompleksnoe Ispol'zovanie Resursov Shel'fa. Sevastopol: ECOSIGidrofizika. Issue 17, pp. 171-175 (in Russian). 
15. Yemeliyanov, V.O., Dovbysh, S.N., Nasedkin, Y.I. and Tsymbaliuk, K.K., 2018. Heavy Metals in the Geological-Ecological System of the Bottom Sediments of the Continental Slope of the Black Sea. Geology and Mineral Resources of World Ocean, (2), pp. 105-113 (in Russian).

16. Kotelyanets, E.A., Gurov, K.I., Tikhonova, E.A. and Kondratev, S.I., 2019. Pollutants in Bottom Sediments in the Balaklava Bay (the Black Sea). Physical Oceanography, 26(5), pp. 414-424. doi:10.22449/1573-160X-2019-5-414-42418

17. Shnyukov, E.F., Orlovsky, G.N., Usenko, V.P., Grigor'ev, A.V. and Gordievich, V.A., 1974. Geology of the Sea of Azov. Kiev: Naukova Dumka, 247 p. (in Russian).

18. Khrustalev, Yu.P., 1989. Regularities of the Sedimentation in the Inland Seas of the Arid Zone. Leningrad: Nauka, 261 p. (in Russian).

19. Khrustalev, Yu.P., 1999. The Fundamental Problems of the Sedimentogenesis Geochemistry in the Azov Sea. Apatity: MMBI KSC RAS, 247 p. (in Russian).

20. Romanov, A.S., Orekhova, N.A., Ignatyeva, O.G., Konovalov, S.K. and Ovsyany, E.I., 2007. Influence of Physico-Chemical Characteristics of the Bottom Sediments on the Trace Elements' Distribution by the Example of Sevastopol Bays (Black Sea). Ekologiya Morya = Ecology of the Sea, 73, pp. 85-90 (in Russian).

21. Gurov, K.I., Ovsyany, E.I., Kotel'yanets, E.A. and Konovalov, S.K., 2014. Geochemical Characteristics of Bottom Sediments in the Kalamita Bay Water Area in the Black Sea. Morskoj Gidrofizicheskij Zhurnal, (5), pp. 69-80 (in Russian).

22. Orekhova, N.A. and Ovsyany, E.I., 2020. Organic Carbon and Particle-Size Distribution in the Littoral Bottom Sediments of the Laspi Bay (the Black Sea). Physical Oceanography, 27(3), pp. 266-277. doi:10.22449/1573-160X-2020-3-266-277

23. Korpakova, I.G., Klenkin, A.A., Konev, Yu.A., Eletsky, B.D., Katalevsky, N.I. and Pavlenko, L.F., 2005. A New Approach to Assessing the Pollution of the Azov Sea Bottom Sediments. Ecological Bulletin of Research Centers of the Black Sea Economic Cooperation, (2), pp. 4553 (in Russian).

24. Klenkin, A.A., Korpakova, I.G., Pavlenko, L.F. and Temerdashev, Z.A., 2007. Ecosystem of the Sea of Azov: Anthropogenic Pollution. Krasnodar, 324 p. (in Russian).

25. Koichubekov, B.K., Sorokina, M.A. and Mkhitaryan, X.E., 2014. Sample Size Determination in Planning of Scientific Research. International Journal of Applied and Fundamental Research, (4), pp. $71-74$ (in Russian).

About the authors:

Irina V. Korablina, Head of the Laboratory for Analytical Control of Water Ecosystems, the Azov-Black Sea branch of FSBSI "VNIRO” (“AzNIIRKH”) (21в Beregovaya str., Rostov-onDon, 344002, Russian Federation), ORCID ID: 000-0002-3995-9425, korablina_i_v@azniirkh.ru

Timofey O. Barabashin, Deputy Director of the Laboratory for Analytical Control of Water Ecosystems, the Azov-Black Sea branch of FSBSI "VNIRO” (“AzNIIRKH”) (21в Beregovaya str., Rostov-on-Don, 344002, Russian Federation), Ph. D. (Biology), ORCID ID: 0000-0002-4103-6224, barabashin_t_o@azniirkh.ru

Nikolay I. Katalevsky, Leading Research Associate, Department of State Monitoring of Aquatic Bioresources and Their Habitat, the Azov-Black Sea branch of FSBSI "VNIRO" (“AzNIIRKH”) (21в Beregovaya str., Rostov-on-Don, 344002, Russian Federation), Ph. D. (Chem.), SPIN-code: 6895-6083, azchem@yandexh.ru 
Contribution of the co-authors:

Irina V. Korablina - preparation of text, data analysis, preparation of a literature review

Timofey O. Barabashin - general paper writing guidance

Nikolay I. Katalevsky - calculation and data analysis

All the authors have read and approved the final manuscript.

The authors declare that they have no conflict of interest. 